\title{
A Study on the Impact of Learning Management System on Students of the University of Jordan
}

\author{
Nabeel Al-Assaf ${ }^{1}$, Tamara Almarabeh ${ }^{2}$, Lubna Nasir Eddin ${ }^{1}$ \\ ${ }^{1}$ Department of Computer Science, King Abdullah II School for Information Technology, The University of \\ Jordan, Amman, Jordan \\ ${ }^{2}$ Department of Computer Information Systems, King Abdullah II School for Information Technology, The \\ University of Jordan, Amman, Jordan \\ Email: n.alassaf@ju.edu.jo, t.almaraabeh@ju.edu.jo, Lubna@ju.edu.jo
}

Received 2 October 2015; accepted 16 November 2015; published 19 November 2015

Copyright (C) 2015 by authors and Scientific Research Publishing Inc.

This work is licensed under the Creative Commons Attribution International License (CC BY).

http://creativecommons.org/licenses/by/4.0/

(c) (i) Open Access

\section{Abstract}

Despite of the advantages of Information and Communication Technology (ICT) which makes our lives easier, faster, and more connected, the development of ICT is pushing the countries in the direction of ICT applications. The higher education is one of the sectors that try to adopt one of ICT applications through E-learning and using (Moodle) as learning management system. This paper finds out the impact of Moodle on students through examining the students' acceptance of the system using TAM model. This study was carried out by some teaching members of the Faculty of King Abdullah II School for Information Technology at the University of Jordan during the spring semester of the academic year $2013 / 2014$. The results of this study firm the original TAM's findings and reveal that the faculties of students and number of previously E-learning courses have an influence on perceive ease of use and perceived usefulness while the level of the academic year and GPA have no significant influence on perceived ease of use. Even though, they have affected on perceived usefulness. Finally, the student's skills on computer with student's difficulty in reading from the screen affect perceived ease of use but, it has been found that they have no influence on perceived usefulness.

\section{Keywords}

E-Learning, Moodle, Technology Acceptance Model, SPSS, The University of Jordan

\section{Introduction}

Nowadays, there is a substantial growth in the use of E-learning platforms in higher education from universities 
around the world [1]. E-learning [2] appeared to let the student use the internet as a tool in his/her study, also to let the teacher to provide the learning material and evaluation techniques using internet. In addition, BlendedLearning [3] was introduced to reduce the drawbacks of E-learning, which omitted the interactive learning, and introduced the use of technology as a tool along besides the interactive learning. Also, Mobile-Learning [4] was used according to the spread use of mobiles among most of students in all stages.

The vision of E-learning in Jordan is "Enhancing the quality of education and inspiring lifelong learning through E-learning”. The University of Jordan (http://www.ju.edu.jo) translated this vision and moved it to the ground by using Blackboard in 2005 as E-learning management system. Then, the Blackboard system was replaced by the Open Source Moodle. The University of Jordan started to use Moodle in 2012 instead of Blackboard as its main learning management system, i.e. the teacher could upload the course description, material, assignments, news about the courses, and online quizzes. The rolled student can check these announcements, download the E-material, assignments, solve them and upload them again on Moodle, or perform online quizzes.

The new technologies and systems can fail because the end users do not accept to use them. Moodle is a new system which means that it can be accepted or rejected by end users. There are many theories of technology acceptance used to appreciate the perceptions of end users, i.e. TRA model, several MIS models, and TAM model. TRA is a general model applicable to many regions. Then, many MIS models have been derived from TRA model. They are more specific in the understudy areas. One of these models is called Technology Acceptance Model (TAM) [5]. The goal of TAM is to "predict information system acceptance and diagnose design problems before users have experience with a system" [5]. There are two main factors that TAM depends on to predict user acceptance of any technology; perceived usefulness and perceived ease of use.

- Perceived usefulness (U) is defined as "the degree to which a user believes that using the system will enhance his or her performance" [5].

- Perceived ease of use (EOU) is defined as "the degree to which the user believes that using the system will be free from effort" [5].

According to TAM [5] shown in "Figure 1", U and EOU are the significant factors that affect the user's attitude toward using the technology system. The feelings of favorableness or un-favorableness toward the system are called (A) i.e. Attitude which is a general concept that is not related to any certain beliefs about technology. This leads to the definition of behavioral intentions to use the system (BI) which is modeled as a function of A and $\mathrm{U}$. BI measures the actual use of technology [6]. BI is the strongest predictor of actual use as studies show [6].

This paper aims to study the impact of Learning Management System (Moodle) on students of The University of Jordan King Abdullah II School for Information Technology according to TAM model with external variables suggested by the authors. A survey was designed for this purpose. It was spread among students in different classes. The answers of the students were collected and analyzed using SPSS software for statistical analysis. Further specifications of the study steps and analysis will be discussed in details in the coming parts of the paper.

\section{Literature Review}

To start with, in 2007 (Ngai, et al.) performed an empirical study for the adoption of WebCT using Tam model, where WebCT is a Web Course Tool used to support E-Learning for The Hong Kong Polytechnic University

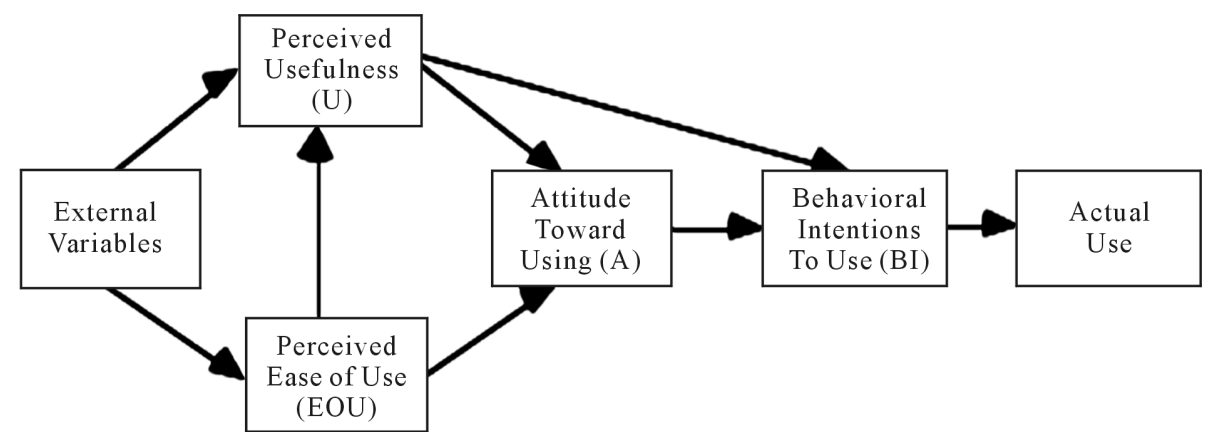

Figure 1. Technology acceptance model (Davis et al.). 
students. This study showed that it important to mediate the relationship of technical support with attitude and WEBCT usage, which depends on both perceived ease of use and perceived usefulness according to TAM [7].

While, in 2007 (Pei-Chen Sun, et al.) studies the critical factors that influence the students satisfaction. Their study was also an empirical one, where they investigate what a successful E-Learning needs using a survey designed for this purpose. Their study showed many critical factors affect learners' perceived satisfaction. They were listed as: student computer anxiety, instructor attitude toward E-Learning, E-Learning course flexibility, ELearning course quality, perceived usefulness, perceived ease of use, and diversity in assessments [8].

In 2008, to understand user behavior towards online learning systems, (ZHANG Sheng et al.) extended TAM model for Online Learning Systems. An online survey was used. The results showed that the variance of online learning system use behavior is higher than that of the original TAM model with $71.3 \%$ percentage [9].

Later, in 2008 S. Y. Park studied the students' behavioral intention to use E-Learning at universities of Korea. Hiss study evolved 628 students, and then it recommended TAM to be used as a theoretical tool to study and measure the acceptance of E-Learning [10].

All the previously discussed studies were focusing on E-learning Systems, while in 2012 (S. Y. Park et al.) concentrated on Mobile-Learning in a new study that measure the behavioral intention to use mobile learning for a sample of 288 students at Konkuk university at Korea. The results of study showed that the TAM model is acceptable to explain students' acceptance of Mobile-Learning [11].

Many Arabian countries researchers developed several studies involving TAM model. For example, in 2013 (A. Tarhini et al.) studied the factors affecting students' acceptance of E-Learning environments using TAM model in Lebanon among university students. This research used a quantitative methodology approach. The results of the study showed that the significant determinants of students' behavioral intention are: perceived usefulness, perceived ease of use, social norms, and Quality of Work life [12].

In the same year, the same authors made another research to extend the TAM model to investigate the students' behavioral intention to use E-Learning. This study aimed to add to TAM two other factors: social norms, and quality of work life. This makes TAM more for developing countries, such as Lebanon. This time, their study was empirical by spreading a survey for 569 both undergraduate and postgraduate students in Lebanon's universities. The results showed that policy makers consider that e-learning is affected by social and cultural factors [13].

These results were also confirmed by Ali Tarhini et al. by their study for user acceptance for Web-based Learning Systems. Their study focused on the role of social, organizational and individual factors. The study considered 604 students who were using web-based learning systems at Brunel University in England. The results showed that individual differences should be taken into consideration when considering success factors such as social, institutional and individual factors in any E-Learning system which should not considered simply as a technological solution [14].

In the same year, another study was performed by M. A. Shahrabia et al. at Shahid Beheshti University in Iran. Their results have proved that TAM model continued to provide sufficient content validity and reliability [15].

\section{Research Methodology}

This study is an extension of a previous study carried out by teaching members of the Faculty of King Abdullah II for Information Technology at The University of Jordan during the spring semester of the academic year 2013/2014 [16] where the researchers studied three external variables affect the ease of use and the expected usefulness, namely: the faculty, academic year, and the student's GPA while the researchers here adopted 6 external variables, and apply the whole TAM model (i.e. they adopted actual use of the system) which is not adopted in the previous study.

\subsection{Sample}

The data in this study were gathered via survey distributed to 240 students, 33 of them are excluded because of incomplete data, so the study depended on 207 students from different faculties (medical, scientific, and humanitarian) in different academic years (first, second, third, forth, and fifth) with different GPA's (excellent, very good, good, and fair) during the summer semester 2014/2015 at The University of Jordan. The questions divided in 2 groups, the first group contains 6 questions including the student's faculty, level of academic year, student's 
GPA, number of previously e-learning courses which depended on Moodle, the student's skills on the computer, and the difficulty of reading from a computer screen which are shown in "Table 1". The researchers used these questions as external factors to test if they affect on perceived usefulness of using Moodle and on ease of use this learning management system. The second group contains 25 questions divided to 4 questions for Perceived (EOU), 7 questions for Perceived (U), 5 questions for Attitudes (A), 4 questions for Behavior Intention to use (BI), and 5 questions for actual use (AU). The second group questions used a 5-point Likert scale (strongly agree, agree, neutral, disagree, and strongly disagree) to measure students' response. These questions are adopted from previous information system researches [17] [18]. "Figure 2" shows the research model employed in this study with the following hypotheses.

- H1: The student's faculty type has an influence on Moodle perceived usefulness.

- H2: The student's faculty type has an influence on Moodle perceived ease of use.

- H3: The level of student's academic year has an influence on Moodle perceived usefulness.

- H4: The level of student's academic year has an influence on Moodle perceived ease of use.

- H5: The degree of student's GPA has an influence on Moodle perceived usefulness.

- H6: The degree of student's GPA has an influence on Moodle perceived ease of use.

- H7: The number of previously E-learning courses has an influence on Moodle perceived usefulness.

- H8: The number of previously E-learning courses has an influence on Moodle perceived ease of use.

- H9: The student's skills on computer and internet affect positively on Moodle perceived usefulness.

- H10: The student's skills on computer and internet affect positively on Moodle perceived ease of use.

Table 1. Sample demographics.

\begin{tabular}{|c|c|c|c|}
\hline Variable & Characteristics & Frequency & Percent \\
\hline \multirow{3}{*}{ Type of Faculty } & Medical & 49 & 23.7 \\
\hline & Scientific & 93 & 44.9 \\
\hline & Humanities & 65 & 31.4 \\
\hline \multirow{5}{*}{ Level of Academic Year } & First & 69 & 33.3 \\
\hline & Second & 61 & 29.5 \\
\hline & Third & 44 & 21.3 \\
\hline & Forth & 28 & 13.5 \\
\hline & Fifth & 5 & 2.4 \\
\hline \multirow{4}{*}{ Student's GPA } & Fair & 18 & 8.7 \\
\hline & Good & 82 & 39.6 \\
\hline & Very good & 80 & 38.6 \\
\hline & Excellent & 27 & 13.0 \\
\hline \multirow{3}{*}{$\begin{array}{c}\text { No. of Previous E-Learning } \\
\text { Courses }\end{array}$} & One Course & 42 & 20.3 \\
\hline & Two courses & 65 & 31.4 \\
\hline & Three Courses or more & 100 & 48.3 \\
\hline \multirow{3}{*}{ Student's Computer Skills } & Excellent Skills & 97 & 46.9 \\
\hline & Moderate Skills & 101 & 48.8 \\
\hline & Weak Skills & 9 & 4.3 \\
\hline \multirow{3}{*}{$\begin{array}{l}\text { Difficulties Reading Form } \\
\text { the Computer Screen }\end{array}$} & Yes & 15 & 7.2 \\
\hline & Moderate & 89 & 43.0 \\
\hline & None & 103 & 49.8 \\
\hline
\end{tabular}




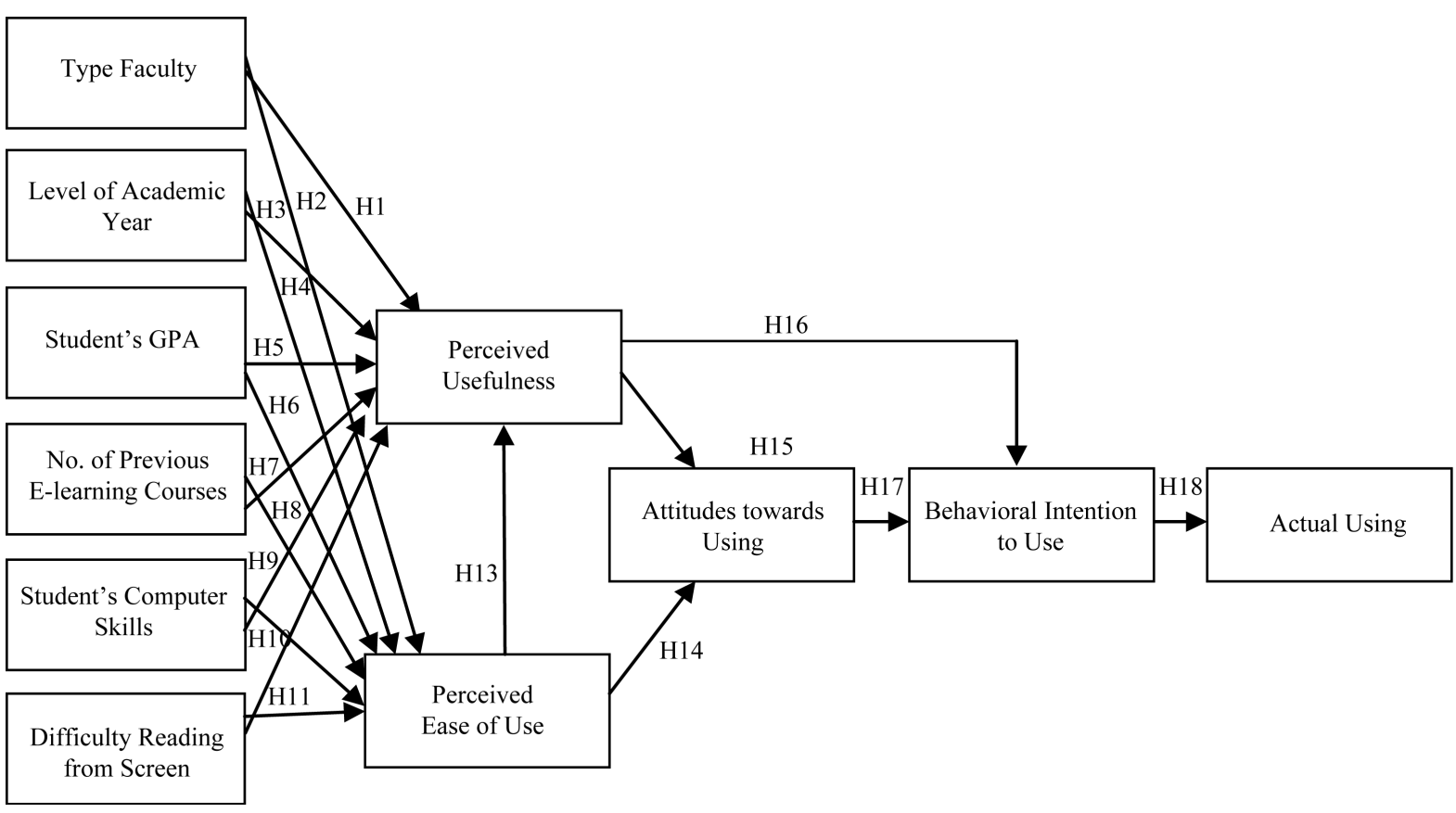

Figure 2. The research model (TAM model with the hypotheses).

- H11: The student's difficulty reading from computer screen affect negatively Moodle perceived usefulness.

- H12: The student's difficulty reading from computer screen affects negatively Moodle perceived ease of use.

- H13: The Perceived ease of use affects positively perceived usefulness of Moodle.

- H14: The Perceived ease of use affects positively attitude towards using Moodle.

- H15: The Perceived usefulness affects positively attitude towards using Moodle.

- H16: The Perceived usefulness affects positively behavioral intention to use Moodle.

- H17: Attitude towards using affects positively behavioral intention to use Moodle.

- H18: Behavioral intention to use affects positively actual using Moodle.

\subsection{Measures}

Measurement validity in terms of reliability and construct validity was evaluated. The reliability analysis measured the internal validity and consistency of questions used for each construct by calculating Cronbach's alpha coefficient [19]. Flynn et al. [20] argued that a Cronbach's alpha of 0.6 and above was considered an effective reliability for judging a scale. In this study, the Cronbach's alpha was higher than 0.6 as shown in "Table 2" which implies that the instrument is reliable.

\subsection{Discussion and Results}

In testing the hypotheses, for the external variables the researchers used one way ANOVA with pre-set level of significance is 0.05 followed by Post Hoc tests to examine the differences between the students in their perceived usefulness and perceived ease of use for the learning management system (Moodle) based on their demographics.

The type of faculty has significant influence on both perceived usefulness and perceived ease of use as shown in "Table 3" (H1 and H2 are supported). Post Hoc Tests are shown in "Table 4", to specify that Perceived ease of use were as follows: medicine and scientific and humanitarian respectively. This returns to the nature of medical and scientific courses, materials and the way of teaching and learning which need more working on the computer and internet with search engines than humanities faculties, which affect positively on both perceived usefulness and perceived ease of use. 
Table 2. Cronbach’s alpha.

\begin{tabular}{ccc}
\hline Item & Number of Items & Cronbach’s Alpha \\
\hline Perceived Ease of Use & 4 & 0.823 \\
Perceived Usefulness & 7 & 0.752 \\
Attitudes toward Usage & 5 & 0.789 \\
Behavioral Intention to Use & 4 & 0.667 \\
Actual Use & 5 & 0.844 \\
\hline
\end{tabular}

Table 3. One way ANOVA: type of faculty.

\begin{tabular}{|c|c|c|c|c|c|c|}
\hline & & Sum of Squares & df & Mean Square & $\mathrm{F}$ & Sig. \\
\hline \multirow{3}{*}{ Perceived Ease of Use } & Between Groups & 82.951 & 2 & 41.476 & 6.584 & 0.002 \\
\hline & Within Groups & 1285.116 & 204 & 6.300 & & \\
\hline & Total & 1368.068 & 206 & & & \\
\hline \multirow{3}{*}{ Perceived Usefulness } & Between Groups & 334.728 & 2 & 167.364 & 13.384 & 0.000 \\
\hline & Within Groups & 2550.924 & 204 & 12.505 & & \\
\hline & Total & 2885.652 & 206 & & & \\
\hline
\end{tabular}

Table 4. Post hoc test: type of faculty.

\begin{tabular}{|c|c|c|c|c|c|c|c|}
\hline \multirow{2}{*}{$\begin{array}{l}\text { Dependent } \\
\text { Variable }\end{array}$} & \multirow{2}{*}{ (I) College } & \multirow{2}{*}{ (J) College } & \multirow{2}{*}{$\begin{array}{c}\text { Mean } \\
\text { Difference (I-J) }\end{array}$} & \multirow{2}{*}{ Std. Error } & \multirow{2}{*}{ Sig. } & \multicolumn{2}{|c|}{ 95\% Confidence Interval } \\
\hline & & & & & & Lower Bound & Upper Bound \\
\hline \multirow{6}{*}{$\begin{array}{l}\text { Perceived } \\
\text { Ease of Use }\end{array}$} & \multirow{2}{*}{ Medical } & Scientific & $0.89598^{*}$ & 0.44306 & 0.044 & 0.0224 & 1.7695 \\
\hline & & Humanities & $1.71931^{*}$ & 0.47485 & 0.000 & 0.7831 & 2.6555 \\
\hline & \multirow{2}{*}{ Scientific } & Medical & $-0.89598^{*}$ & 0.44306 & 0.044 & -1.7695 & -0.0224 \\
\hline & & Humanities & $0.82333^{*}$ & 0.40578 & 0.044 & 0.0233 & 1.6234 \\
\hline & \multirow{2}{*}{ Humanities } & Medical & $-1.71931^{*}$ & 0.47485 & 0.000 & -2.6555 & -0.7831 \\
\hline & & Scientific & $-0.82333^{*}$ & 0.40578 & 0.044 & -1.6234 & -0.0233 \\
\hline \multirow{6}{*}{$\begin{array}{l}\text { Perceived } \\
\text { Usefulness }\end{array}$} & \multirow{2}{*}{ Medical } & Scientific & $2.17182^{*}$ & 0.62422 & 0.001 & 0.9411 & 3.4026 \\
\hline & & Humanities & $3.45024^{*}$ & 0.66901 & 0.000 & 2.1312 & 4.7693 \\
\hline & \multirow{2}{*}{ Scientific } & Medical & $-2.17182^{*}$ & 0.62422 & 0.001 & -3.4026 & -0.9411 \\
\hline & & Humanities & $1.27841^{*}$ & 0.57169 & 0.026 & 0.1512 & 2.4056 \\
\hline & \multirow{2}{*}{ Humanities } & Medical & $-3.45024^{*}$ & 0.66901 & 0.000 & -4.7693 & -2.1312 \\
\hline & & Scientific & $-1.27841^{*}$ & 0.57169 & 0.026 & -2.4056 & -0.1512 \\
\hline
\end{tabular}

Regarding the academic year, the level of academic year is influenced on perceived usefulness (H3 is supported) while no statistically influence on perceived ease of use (H4 is rejected) as shown in "Table 5". The Post Hoc test in "Table 6" shows that the students of academic year: second, third, fourth and fifth levels are better than the students in the first level and this is normal situation because these students are studied more than 1 course in the university which depend on Moodle and have more awareness of its importance than students are fresh graduate from high schools, especially, School students do not depend on use of computer applications through their study nor they use any learning management system in their schools. 
Table 5. One way ANOVA: level of academic year.

\begin{tabular}{ccccccc}
\hline & & Sum of Squares & df & Mean Square & F & Sig. \\
\hline & Between Groups & 38.741 & 4 & 9.685 & 1.472 & 0.212 \\
Perceived Ease of Use & Within Groups & 1329.327 & 202 & 6.581 & & \\
& Total & 1368.068 & 206 & & & 0.010 \\
\hline \multirow{2}{*}{ Perceived Usefulness } & Between Groups & 181.546 & 4 & 45.386 & 3.390 & 13.387 \\
& Within Groups & 2704.106 & 202 & & & \\
\hline
\end{tabular}

Table 6. Post hoc test: level of academic year.

\begin{tabular}{|c|c|c|c|c|c|c|c|}
\hline \multirow{2}{*}{$\begin{array}{l}\text { Dependent } \\
\text { Variable }\end{array}$} & \multirow{2}{*}{ (I) Year } & \multirow{2}{*}{ (J) Year } & \multirow{2}{*}{$\begin{array}{c}\text { Mean } \\
\text { Difference (I-J) }\end{array}$} & \multirow{2}{*}{ Std. Error } & \multirow{2}{*}{ Sig. } & \multicolumn{2}{|c|}{ 95\% Confidence Interval } \\
\hline & & & & & & Lower Bound & Upper Bound \\
\hline \multirow{20}{*}{$\begin{array}{l}\text { Perceived } \\
\text { Usefulness }\end{array}$} & \multirow{4}{*}{ First } & Second & $-1.50059^{*}$ & 0.64301 & 0.021 & -2.7685 & -0.2327 \\
\hline & & Third & $-1.92161^{*}$ & 0.70587 & 0.007 & -3.3134 & -0.5298 \\
\hline & & Forth & $-1.87940^{*}$ & 0.81982 & 0.023 & -3.4959 & -0.2629 \\
\hline & & Fifth & $-4.05797^{*}$ & 1.69450 & 0.018 & -7.3992 & -0.7168 \\
\hline & \multirow{4}{*}{ Second } & First & $1.50059^{*}$ & 0.64301 & 0.021 & 0.2327 & 2.7685 \\
\hline & & Third & -0.42101 & 0.72367 & 0.561 & -1.8479 & 1.0059 \\
\hline & & Forth & -0.37881 & 0.83519 & 0.651 & -2.0256 & 1.2680 \\
\hline & & Fifth & -2.55738 & 1.70199 & 0.135 & -5.9133 & 0.7986 \\
\hline & \multirow{4}{*}{ Third } & First & $1.92161^{*}$ & 0.70587 & 0.007 & 0.5298 & 3.3134 \\
\hline & & Second & 0.42101 & 0.72367 & 0.561 & -1.0059 & 1.8479 \\
\hline & & Forth & 0.04221 & 0.88450 & 0.962 & -1.7018 & 1.7862 \\
\hline & & Fifth & -2.13636 & 1.72672 & 0.217 & -5.5411 & 1.2684 \\
\hline & \multirow{4}{*}{ Forth } & First & $1.87940^{*}$ & 0.81982 & 0.023 & 0.2629 & 3.4959 \\
\hline & & Second & 0.37881 & 0.83519 & 0.651 & -1.2680 & 2.0256 \\
\hline & & Third & -0.04221 & 0.88450 & 0.962 & -1.7862 & 1.7018 \\
\hline & & Fifth & -2.17857 & 1.77635 & 0.221 & -5.6811 & 1.3240 \\
\hline & \multirow{4}{*}{ Fifth } & first & $4.05797^{*}$ & 1.69450 & 0.018 & 0.7168 & 7.3992 \\
\hline & & Second & 2.55738 & 1.70199 & 0.135 & -0.7986 & 5.9133 \\
\hline & & Third & 2.13636 & 1.72672 & 0.217 & -1.2684 & 5.5411 \\
\hline & & Forth & 2.17857 & 1.77635 & 0.221 & -1.3240 & 5.6811 \\
\hline
\end{tabular}

As shown in “Table 7”, the hypothesis H5 is supported (sig < 0.05) which means the degree of GPA has a significant influence on perceived usefulness but the GPA has no statistically influence on perceived ease of use (H6 is rejected) which is normal because the students can get excellent GPA in their faculties and specialization courses without having a good skills in using computer and internet especially if the instructor does not depend on Moodle to transfer the teaching material to students or to perform online quizzes. This effect appears more strongly in humanities faculties.

By conducting Post Hoc test in "Table 8" to find out which of the four categories of GPA has the most influence on perceived usefulness, the results indicated that excellent GPA has the most impact, followed by very 
Table 7. One way ANOVA: student’s GPA.

\begin{tabular}{cccccc}
\hline & & Sum of Squares & df & Mean Square & F \\
& Between Groups & 20.877 & 3 & 6.959 & 1.049 \\
Perceived Ease of Use & Within Groups & 1347.191 & 203 & 6.636 \\
& Total & 1368.068 & 206 & 372 \\
\hline & Between Groups & 329.525 & 3 & 109.842 \\
Perceived Usefulness & Within Groups & 2556.127 & 203 & 12.592 \\
\hline
\end{tabular}

Table 8. Post hoc test: student's GPA.

\begin{tabular}{|c|c|c|c|c|c|c|c|}
\hline \multirow{2}{*}{$\begin{array}{l}\text { Dependent } \\
\text { Variable }\end{array}$} & \multirow{2}{*}{ (I) avg } & \multirow{2}{*}{ (J) avg } & \multirow{2}{*}{$\begin{array}{c}\text { Mean } \\
\text { Difference (I-J) }\end{array}$} & \multirow{2}{*}{ Std. Error } & \multirow{2}{*}{ Sig. } & \multicolumn{2}{|c|}{ 95\% Confidence Interval } \\
\hline & & & & & & Lower Bound & Upper Bound \\
\hline \multirow{12}{*}{$\begin{array}{l}\text { Perceived } \\
\text { Usefulness }\end{array}$} & \multirow{3}{*}{ Fair } & Good & $-1.99458^{*}$ & 0.92363 & 0.032 & -3.8157 & -0.1734 \\
\hline & & Very good & $-3.29306^{*}$ & 0.92571 & 0.000 & -5.1183 & -1.4678 \\
\hline & & Excellent & $-4.88889^{*}$ & 1.07977 & 0.000 & -7.0179 & -2.7599 \\
\hline & \multirow{3}{*}{ Good } & Fair & $1.99458^{*}$ & 0.92363 & 0.032 & 0.1734 & 3.8157 \\
\hline & & Very good & $-1.29848^{*}$ & 0.55763 & 0.021 & -2.3980 & -0.1990 \\
\hline & & Excellent & $-2.89431^{*}$ & 0.78735 & 0.000 & -4.4467 & -1.3419 \\
\hline & \multirow{3}{*}{ Very good } & Fair & $3.29306^{*}$ & 0.92571 & 0.000 & 1.4678 & 5.1183 \\
\hline & & Good & $1.29848^{*}$ & 0.55763 & 0.021 & 0.1990 & 2.3980 \\
\hline & & Excellent & $-1.59583^{*}$ & 0.78978 & 0.045 & -3.1531 & -0.0386 \\
\hline & \multirow{3}{*}{ Excellent } & Fair & $4.88889^{*}$ & 1.07977 & 0.000 & 2.7599 & 7.0179 \\
\hline & & Good & $2.89431^{*}$ & 0.78735 & 0.000 & 1.3419 & 4.4467 \\
\hline & & Very good & $1.59583^{*}$ & 0.78978 & 0.045 & 0.0386 & 3.1531 \\
\hline
\end{tabular}

good, good and finally fair which shows positive relationship between GPA and the students' awareness of the benefits.

The number of previous e-learning courses which depend on Moodle has significant influence on both perceived usefulness and perceived ease of use as shown in "Table 9" (H7 and H8 are supported). Post Hoc Tests are shown in "Table 10" to specify that students who studied 2 or 3 E-learning courses find Moodle easier to use than the students who studied only 1 course and more awareness of its importance.

The student's computer skills have significant influence on perceived ease of use as shown in "Table 11" (H10 is supported) but not on perceived usefulness (H9 is rejected) and this is an expected situation. Post Hoc Tests are shown in "Table 12" to specify those students with excellent skills on computers found the portal easier to use than students with moderate skills and the students with moderate skills on computers found the portal easier to use with weak skills.

As shown in "Table 13", the hypothesis H12 is supported (sig $<0.05$ ) which means the difficulty of reading from a computer screen has a significant influence on perceived ease of use but no statistically influence on perceived usefulness (H11 is rejected). Post hoc Test in "Table 14" shows that students with no difficulties of reading from computer screen are finding Moodle is easier to use than students with difficulties of reading from computer screens.

For testing the original TAM model, the researchers used a regression analyses and found all the hypotheses are supported as shown in "Table 15" and "Table 16". 
In linear regression matrix there are five parameters; R2-Value (the coefficient of the correlation or the relation) which shows the strength and direction of the relationship. P-Value indicates the significant of the relationship, $\mathrm{P}$ must always equal or less than 0.05 for the relationship to be significant. Beta, $\beta$-Value which is another parameter in linear regression shows the slope and the direction of the relationship, standard error SE Value of $\beta$ indicates the percentage of error that can happen. The smaller the standard error of $\beta$ the less likely error can happen while $t$ statistics is the coefficient divided by its error. As reader can see in "Table 15", the

Table 9. One way ANOVA: number of E-learning courses.

\begin{tabular}{|c|c|c|c|c|c|c|}
\hline & & Sum of Squares & Df & Mean Square & $\mathrm{F}$ & Sig. \\
\hline \multirow{3}{*}{ Perceived Ease of Use } & Between Groups & 135.826 & 2 & 67.913 & 11.243 & 0.000 \\
\hline & Within Groups & 1232.242 & 204 & 6.040 & & \\
\hline & Total & 1368.068 & 206 & & & \\
\hline \multirow{3}{*}{ Perceived Usefulness } & Between Groups & 205.112 & 2 & 102.556 & 7.805 & 0.001 \\
\hline & Within Groups & 2680.540 & 204 & 13.140 & & \\
\hline & Total & 2885.652 & 206 & & & \\
\hline
\end{tabular}

Table 10. Post hoc test. Number of previous E-learning courses.

\begin{tabular}{|c|c|c|c|c|c|c|c|}
\hline \multirow{2}{*}{$\begin{array}{l}\text { Dependent } \\
\text { Variable }\end{array}$} & \multirow{2}{*}{ (I) E_courses } & \multirow{2}{*}{ (J) E_courses } & \multirow{2}{*}{$\begin{array}{c}\text { Mean } \\
\text { Difference (I-J) }\end{array}$} & \multirow{2}{*}{ Std. Error } & \multirow{2}{*}{ Sig. } & \multicolumn{2}{|c|}{ 95\% Confidence Interval } \\
\hline & & & & & & Lower Bound & Upper Bound \\
\hline \multirow{6}{*}{$\begin{array}{c}\text { Perceived } \\
\text { Ease of Use }\end{array}$} & \multirow{2}{*}{ One Course } & Two courses & $-1.93260^{*}$ & 0.48657 & 0.000 & -2.8919 & -0.9733 \\
\hline & & Three Courses or more & $-2.05952^{*}$ & 0.45191 & 0.000 & -2.9505 & -1.1685 \\
\hline & \multirow{2}{*}{ Two courses } & One Course & $1.93260^{*}$ & 0.48657 & 0.000 & 0.9733 & 2.8919 \\
\hline & & Three Courses or more & -0.12692 & 0.39158 & 0.746 & -0.8990 & 0.6451 \\
\hline & \multirow{2}{*}{$\begin{array}{c}\text { Three Courses } \\
\text { or more }\end{array}$} & One Course & 2.05952 & 0.45191 & 0.000 & 1.1685 & 2.9505 \\
\hline & & Two courses & 0.12692 & 0.39158 & 0.746 & -0.6451 & 0.8990 \\
\hline \multirow{6}{*}{$\begin{array}{l}\text { Perceived } \\
\text { Usefulness }\end{array}$} & \multirow{2}{*}{ One Course } & Two courses & -1.30000 & 0.71764 & 0.072 & -2.7149 & 0.1149 \\
\hline & & Three Courses or more & $-2.56000^{*}$ & 0.66652 & 0.000 & -3.8742 & -1.2458 \\
\hline & \multirow{2}{*}{ Two courses } & One Course & 1.30000 & 0.71764 & 0.072 & -0.1149 & 2.7149 \\
\hline & & Three Courses or more & $-1.26000^{*}$ & 0.57754 & 0.030 & -2.3987 & -0.1213 \\
\hline & \multirow{2}{*}{$\begin{array}{c}\text { Three Courses } \\
\text { or more }\end{array}$} & One Course & $2.56000^{*}$ & 0.66652 & 0.000 & 1.2458 & 3.8742 \\
\hline & & Two courses & $1.26000^{*}$ & 0.57754 & 0.030 & 0.1213 & 2.3987 \\
\hline
\end{tabular}

Table 11. One way ANOVA: student's computer skills.

\begin{tabular}{|c|c|c|c|c|c|c|}
\hline & & Sum of Squares & df & Mean Square & $\mathrm{F}$ & Sig. \\
\hline \multirow{3}{*}{ Perceived Ease of Use } & Between Groups & 96.568 & 2 & 48.284 & 7.747 & 0.001 \\
\hline & Within Groups & 1271.500 & 204 & 6.233 & & \\
\hline & Total & 1368.068 & 206 & & & \\
\hline \multirow{3}{*}{ Perceived Usefulness } & Between Groups & 1.443 & 2 & 0.721 & 0.051 & 0.950 \\
\hline & Within Groups & 2884.209 & 204 & 14.138 & & \\
\hline & Total & 2885.652 & 206 & & & \\
\hline
\end{tabular}


Table 12. Post hoc test: student's computer skills.

\begin{tabular}{|c|c|c|c|c|c|c|c|}
\hline \multirow{2}{*}{$\begin{array}{l}\text { Dependent } \\
\text { Variable }\end{array}$} & \multirow{2}{*}{ (I) Skills } & \multirow{2}{*}{ (J) Skills } & \multirow{2}{*}{$\begin{array}{c}\text { Mean } \\
\text { Difference (I-J) }\end{array}$} & \multirow{2}{*}{ Std. Error } & \multirow{2}{*}{ Sig. } & \multicolumn{2}{|c|}{ 95\% Confidence Interval } \\
\hline & & & & & & Lower Bound & Upper Bound \\
\hline \multirow{6}{*}{ Ease of Use } & \multirow{2}{*}{ Excellent Skills } & Moderate Skills & $0.89548^{*}$ & 0.35492 & 0.012 & 0.1957 & 1.5953 \\
\hline & & Weak Skills & $3.02749^{*}$ & 0.86994 & 0.001 & 1.3123 & 4.7427 \\
\hline & \multirow{2}{*}{ Moderate Skills } & Excellent Skills & $-0.89548^{*}$ & 0.35492 & 0.012 & -1.5953 & -0.1957 \\
\hline & & Weak Skills & $2.13201^{*}$ & 0.86848 & 0.015 & 0.4197 & 3.8444 \\
\hline & \multirow{2}{*}{ Weak Skills } & Excellent Skills & -3.02749 & 0.86994 & 0.001 & -4.7427 & -1.3123 \\
\hline & & Moderate Skills & -2.13201 & 0.86848 & 0.015 & -3.8444 & -0.4197 \\
\hline
\end{tabular}

Table 13. One way ANOVA: difficulty of reading from a computer screen.

\begin{tabular}{|c|c|c|c|c|c|c|}
\hline & & Sum of Squares & df & Mean Square & $\mathrm{F}$ & Sig. \\
\hline \multirow{3}{*}{ Perceived Ease of Use } & Between Groups & 95.003 & 2 & 47.501 & 7.612 & 0.001 \\
\hline & Within Groups & 1273.065 & 204 & 6.241 & & \\
\hline & Total & 1368.068 & 206 & & & \\
\hline \multirow{3}{*}{ Perceived Usefulness } & Between Groups & 67.580 & 2 & 33.790 & 2.446 & 0.089 \\
\hline & Within Groups & 2818.072 & 204 & 13.814 & & \\
\hline & Total & 2885.652 & 206 & & & \\
\hline
\end{tabular}

Table 14. Post hoc test: difficulty of reading from a computer screen.

\begin{tabular}{|c|c|c|c|c|c|c|c|}
\hline \multirow{2}{*}{$\begin{array}{l}\text { Dependent } \\
\text { Variable }\end{array}$} & \multirow{2}{*}{ (I) Difficulties } & \multirow{2}{*}{ (J) Difficulties } & \multirow{2}{*}{$\begin{array}{c}\text { Mean } \\
\text { Difference (I-J) }\end{array}$} & \multirow{2}{*}{ Std. Error } & \multirow{2}{*}{ Sig. } & \multicolumn{2}{|c|}{ 95\% Confidence Interval } \\
\hline & & & & & & Lower Bound & Upper Bound \\
\hline \multirow{6}{*}{ Ease of Use } & \multirow[b]{2}{*}{ Yes } & Moderate & $-1.61648^{*}$ & 0.69725 & 0.021 & -2.9912 & -0.2417 \\
\hline & & None & $-2.47314^{*}$ & 0.69038 & 0.000 & -3.8343 & -1.1119 \\
\hline & \multirow[b]{2}{*}{ Moderate } & Yes & $1.61648^{*}$ & 0.69725 & 0.021 & 0.2417 & 2.9912 \\
\hline & & None & $-0.85666^{*}$ & 0.36153 & 0.019 & -1.5695 & -0.1438 \\
\hline & \multirow{2}{*}{ None } & Yes & $2.47314^{*}$ & 0.69038 & 0.000 & 1.1119 & 3.8343 \\
\hline & & Moderate & $0.85666^{*}$ & 0.36153 & 0.019 & 0.1438 & 1.5695 \\
\hline
\end{tabular}

Table 15. Regression results for original TAM model hypotheses.

\begin{tabular}{ccccccc}
\hline Independent Variable & $\beta$ & $\mathrm{SE}$ & $\mathrm{T}$ & $\mathrm{P}$ & $\mathrm{R}^{2}$ & Dependent Variable \\
Perceived Ease Of Use & 0.339 & 0.095 & 5.165 & 0.000 & 0.115 & Perceived Usefulness \\
Perceived Ease Of Use & 0.455 & 0.071 & 7.324 & 0.000 & 0.207 & Attitude Towards Using \\
Perceived Usefulness & 0.326 & 0.052 & 4.937 & 0.000 & 0.106 & Attitude Towards Using \\
Perceived Usefulness & 0.214 & 0.046 & 3.144 & 0.002 & 0.046 & Behavioral Intention To Use \\
Attitude Towards Using & 0.529 & 0.051 & 8.936 & 0.000 & 0.280 & Behavioral Intention To Use
\end{tabular}


Table 16. Summary of original TAM model hypotheses with suggested external variables.

\begin{tabular}{|c|c|c|}
\hline Hypothesis & Tested Relationship & Result \\
\hline H1 & The student's faculty type has an influence on Moodle perceived usefulness. & Supported \\
\hline $\mathrm{H} 2$ & The student's faculty type has an influence on Moodle perceived ease of use. & Supported \\
\hline H3 & The level of student's academic year has an influence on Moodle perceived usefulness. & Supported \\
\hline $\mathrm{H} 4$ & The level of student's academic year has an influence on Moodle perceived ease of use. & Not supported \\
\hline H5 & The degree of student's GPA has an influence on Moodle perceived usefulness. & Supported \\
\hline H6 & The degree of student's GPA has an influence on Moodle perceived ease of use. & Not Supported \\
\hline H7 & The number of previously E-learning courses has an influence on Moodle perceived usefulness. & Supported \\
\hline H8 & The number of previously E-learning courses has an influence on Moodle perceived ease of use. & Supported \\
\hline H9 & The student's skills on computer and internet affect positively on Moodle perceived usefulness. & Not supported \\
\hline H10 & The student's skills on computer and internet affect positively on Moodle perceived ease of use. & Supported \\
\hline H11 & The student's difficulty reading from computer screen affect negatively on Moodle perceived usefulness. & Not Supported \\
\hline H12 & The student's difficulty reading from computer screen affect negatively on Moodle perceived ease of use. & Supported \\
\hline H13 & The Perceived ease of use affects positively perceived usefulness of Moodle. & Supported \\
\hline H14 & The Perceived ease of use affects positively on attitude towards using Moodle. & Supported \\
\hline H15 & The Perceived usefulness affects positively on attitude towards using Moodle. & Supported \\
\hline H16 & The Perceived usefulness affects positively on behavioral intention to use Moodle. & Supported \\
\hline H17 & Attitude towards using affects positively on behavioral intention to use Moodle. & Supported \\
\hline H18 & Behavioral intention to use affects positively on actual using Moodle. & Supported \\
\hline
\end{tabular}

results showed that the perceived usefulness has a significant influence $\left(R^{2}=0.106, \beta=0.326\right)$ on the attitudes towards using better than its influence on behavioral intention to use. This returns to The University of Jordan students' awareness to Moodle as learning management system while focusing on its advantages. This research also agrees with other researches to indicate that an attitude towards using is a direct determinant of behavioral intention to use [21] [22].

\section{Conclusions}

This study shows that its obtained results confirm the original TAM Model. It also demonstrates some interesting issues. First: the students of the University of Jordan are highly qualified to use Moodle as learning management system and have sufficient awareness of its benefits. Second: The University of Jordan is working on the improvement of the educational process in its different faculties, so this study can help the decision makers in the University in the development Moodle as learning management system.

Future studies could be conducted to examine TAM with a different sample of students and a wider range of information technology applications, and examine the TAM model with the teachers from the University of Jordan to get more comprehensive view of perception the Moodle.

\section{References}

[1] Paechter, M., Maier, B. and Macher, D. (2010) Students’ Expectations of and Experiences in E-Learning: Their Relation to Learning Achievements and Course Satisfaction. Computers \& Education, 54, 222-229. http://dx.doi.org/10.1016/j.compedu.2009.08.005

[2] Amaral, L.A. and Leal, D. (2004) From Classroom Teaching to E-learning: The Way for a Strong Definition. Universidade do Minho, Braga.

[3] Heinze, A. and Procter, C. (2004) Reflections on the Use of Blended Learning: Education in a Changing Environment. 
Conference Proceedings, Heinze, 13-14 September 2004, 8.

[4] Ferreira, J.B., Klein, A.Z., Freitas, A. and Schlemmer, E. (2013) Mobile Learning: Definition, Uses and Challenges. In: Wankel, L.A. and Blessinger, P., Eds., Increasing Student Engagement and Retention Using Mobile Applications: Smartphones, Skype, and Texting Technologies, Emerald Publishing Group, Bingley, 47-83. http://dx.doi.org/10.1108/S2044-9968(2013)000006D005

[5] Davis, F.D., Bagozzi, R.P. and Warsha, P.R. (1989) User Acceptance of Computer Technology: A Comparison of Two Theoretical Models. Management Science, 35, 982-1003.

[6] Davis, F.D. (1989) Perceived Usefulness, Perceived Ease of Use, and User Acceptance of Information Technology. MIS Quarterly, 13, 319-340. http://dx.doi.org/10.2307/249008

[7] Ngai, E.W.T., Poon J.K.L. and Chan, Y.H.C. (2007) Empirical Examination of the Adoption of WebCT Using TAM. Computers \& Education, 48, 250-267. http://dx.doi.org/10.1016/j.compedu.2004.11.007

[8] Sun, P.-C., Tsai, R.J., Finger, G., Chen, Y.-Y. and Yeh, D. (2007) What Drives a Successful E-Learning? An Empirical Investigation of the Critical Factors Influencing Learner Satisfaction. Computers \& Education, 50, 1183-1202.

[9] Zhang, S., Zhao, J. and Tan, W.W. (2008) Extending TAM for Online Learning Systems: An Intrinsic Motivation Perspective. Tsinghua Science and Technology, 13, 312-317.

[10] Park, S.Y. (2009) An Analysis of the Technology Acceptance Model in Understanding University Students’ Behavioral Intention to Use e-Learning. Educational Technology \& Society, 12, 150-162.

[11] Park, S.Y., Nam, M.-W. and Cha, S.-B. (2012) University Students’ Behavioral Intention to Use Mobile Learning: Evaluating the Technology Acceptance Model. British Journal of Educational Technology, 43, 592-605. http://dx.doi.org/10.1111/j.1467-8535.2011.01229.x

[12] Tarhini, A., Hone, K. and Liu, X.H. (2013) Factors Affecting Students' Acceptance of E-Learning Environments in Developing Countries: A Structural Equation Modeling Approach. International Journal of Information and Education Technology, 3, 54-59.

[13] Tarhini, A., Hone, K. and Liu, X.H. (2013) Extending the TAM Model to Empirically Investigate the Students' Behavioural Intention to Use E-Learning in Developing Countries. Science and Information Conference, 7-9 October 2013, London, 732-737.

[14] Tarhini, A., Hone, K. and Liu, X.H. (2013) User Acceptance towards Web-Based Learning Systems: Investigating the Role of Social, Organizational and Individual factors in European Higher Education. Procedia Computer Science, 17, 189-197. http://dx.doi.org/10.1016/j.procs.2013.05.026

[15] Shahrabia, M.A., Ahaninjan, A., Nourbakhsh, H., Ashlubolagh, M.A., Abdolmaleki, J. and Mohamadi, M. (2013) Assessing Psychometric Reliability and Validity of Technology Acceptance Model (TAM) among Faculty Members at Shahid Beheshti University. Management Science Letters, 3, 2295-2300.

[16] Majadlawi, Y., Almarabeh, T. and Mohammad, H. (2014) Factors Affecting Students’ Usage of Learning Management System at the University of Jordan. Life Science Journal, 11, 666-671.

[17] Masrom, M. (2007) Technology Acceptance Model and E-Learning. 12th International Conference on Education, 2124 May 2007, Brunei Darussalam: Universiti Brunei Darussalam, 1-10.

[18] Sek, Y., Lau, S., Teoh, K. and Law, C. (2010) Prediction of User Acceptance and Adoption of Smart Phone for Learning with Technology Acceptance Model. Journal of Applied Sciences, 10, 2395-2402. http://dx.doi.org/10.3923/jas.2010.2395.2402

[19] Moolla, A. and Bisschoff, C. (2012) Validating a Model to Measure the Brand Loyalty of Fast Moving Consumer Goods. The Social Science Journal, 31, 101-115.

[20] Flynn, B., Schroeder, R. and Sakakibara, S. (1994) A Framework for Quality Management Research and an Associated Measurement Instrument. Journal of Operations Management, 11, 339-366. http://dx.doi.org/10.1016/S0272-6963(97)90004-8

[21] Liu, S., Liao, H. and Pratt, J.A. (2009) Impact of Media Richness and Flow on E-Learning Technology Acceptance. Computers \& Education, 52, 599-607. http://dx.doi.org/10.1016/j.compedu.2008.11.002

[22] Lee, M.K.O., Cheung, C.M.K. and Chen, Z.H. (2005) Internet-Based Learning Medium: The Role of Extrinsic and Intrinsic Motivation. Information \& Management, 42, 1095-1104. http://dx.doi.org/10.1016/j.im.2003.10.007 